\title{
EDWARD PETER SHARPEY-SCHAFER
}

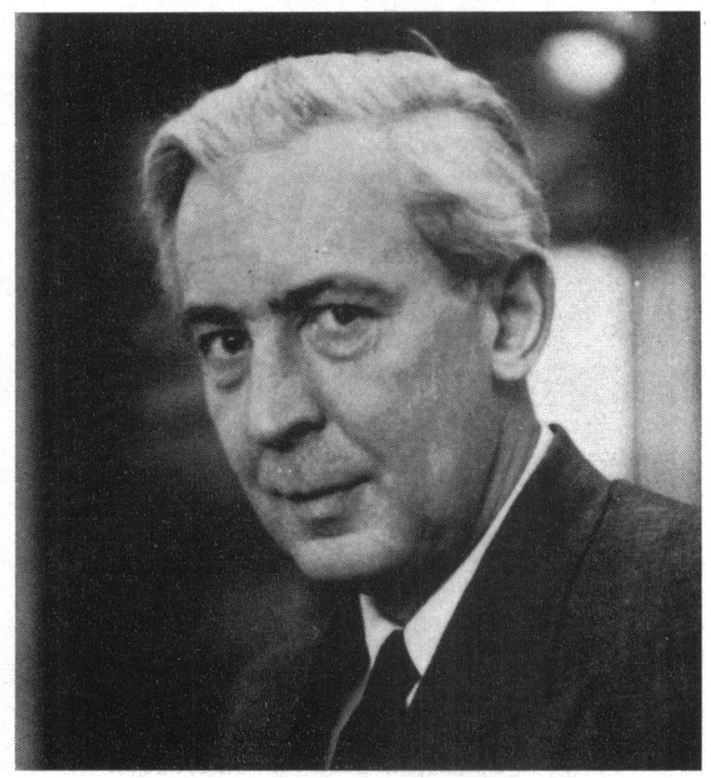

Edward Peter Sharpey-Schafer who died on October 23, 1963 at the age of 55 was the son of Commander John Sharpey-Schafer, R.N. His father lost his life in 1918 in anti-submarine work, and his grandfather, Sir Edward Sharpey-Schafer, F.R.S., who was Professor of Physiology in Edinburgh, took responsibility for the education of his grandsons. Sir Edward was a formidable senior figure in British physiology, remote from his students and inclined to intolerance of those colleagues whom he did not consider to be his intellectual equals, traits that were to emerge in Peter.

Peter went to Winchester as a Scholar, and holidays at North Berwick gave him opportunities of becoming a golfer. He entered King's College, Cambridge as an Exhibitioner and Kitchener Scholar. His clinical education was completed at University College Hospital in 1933 with a conjoint diploma. At that time a thesis was needed to complete the Cambridge M.B. With characteristic disdain and disapproval of this arrangement (now abandoned) Peter never completed his Cambridge degree. This was part of his personal make-up-a disregard of convention that often led to anxieties among those with whom he worked.

His brilliance, however, was already apparent as a student, and he took the Fellowes Gold and Silver Medals. As a young graduate he held the "plum" jobs at University College Hospital as House Surgeon to Mr. Wilfred Trotter and House Physician to Sir Thomas Lewis. He then became Casualty Medical Officer and this was followed by a spell at the National Heart Hospital (following Paul Wood). He took his M.R.C.P. in 1935 and in the following year joined the staff of the newly-founded British Postgraduate Medical School at Hammersmith. Here his chief Professor (now Sir) Francis Fraser had already chosen Robert Aitken as Reader, and as first assistants Paul Wood, J. G. Scadding, and C. H. Stuart Harris. These brilliant percipient selections ensured the academic momentum of the new School whose early staff also included E. H. Kettle, Grey Turner, Janet Vaughan, Ashley Miles, and Earl King. 
Professor Fraser wanted his staff to cover individually the various specialities in medicine. To Wood he allocated cardiology, and Sharpey-Schafer was asked to be responsible for endocrinology. His grandfather had in fact compiled what was, in the 1920s, a splendid monograph on the physiology of the endocrine glands, and the young Sharpey-Schafer's contributions to this subject were quickly apparent. He was early in the use of thyrotrophin as a test for thyroid responsiveness and he did much to establish the "all or none" principle of myxœdema and to show the rarity of hypothyroidism, then frequently diagnosed. The influence of gonadotrophins on the prostate gland was also a subject of study. His main leaning, however, was to the circulation, a field in which he was to make many considerable contributions. He was now developing his talents as physician and teacher. His clinical work was done with quick perception which could appear to be slapdash but which often changed and corrected the whole approach to the problem. Seldom orthodox but invariably precise, his clinics were surprising as unsuspected facets of the problems were revealed and discussed. Systematic lecturing, however, seldom interested him. He was quick to notice the acute responsive mind among his listeners and in those of his juniors who understood him he took the deepest interest.

With the outbreak of war the staff of the department at the Postgraduate Medical School was scattered, though a decision was taken to keep the School in being. As the only teaching hospital which did not leave London, opportunities for the study of "shock" in its various forms were envisaged and indeed materialized. The bleeding of transfusion donors gave opportunities for the study of hæmorrhage, and with John Wallace meticulous studies were made of the rate of blood dilution and plasma protein replacement. The old fallacy of natural replacement of blood loss by a protein-free tissue fluid was quickly exploded by their work. The fainting reaction after bleeding excited interest when, with Barcroft and Edholm, he showed that it was due to vasodilatation in the limbs. By this time cardiac catheterization had been introduced as a technique of study of the circulation and together we used the method of right atrial catheterization in studies of heart failure in its various forms and the effect of various drugs thereon. In 1944 Peter developed tuberculosis which compelled prolonged absence from work. After the end of the war he began to devote more time to the study of the peripheral circulation. Postural changes, and the effect of the Valsalva manœuvre fascinated him. He elevated the latter into a test of cardiac and baroceptor function. All forms of syncope continued to be of much interest, and he demonstrated the absence of baroceptor reflexes in tabes, diabetes, acute porphyria, and other conditions.

For a long time he had thought profoundly on venous tone and the circulation. This interest came from earlier observations on the circulation in anæmia when a high cardiac output and often a high venous pressure could be maintained in spite of a normal or reduced blood volume. His later work led him back to this problem which was the subject of his Oliver Sharpey Lectures to the Royal College of Physicians. At the time of his death he felt he had produced evidence that the veno-constriction after exercise was due to tissue acidosis, and a posthumous publication will appear on this subject.

In 1948 he became Professor of Medicine at St. Thomas' Hospital and was elected F.R.C.P. in 1949. He exerted a profound influence at St. Thomas' focusing the attention of his talented students and trainees on research but combining this with a freedom to develop their own interests. Dornhorst, de Wardener, and Mills all moved from his department to Chairs elsewhere, and many others became medical leaders. Grant Lee, G. L. Leathart, M. B. Matthews, P. Howard, P. Naylor, all owed much to his inspiration and A. J. Buller's interest in the physiology of the nervous system owed much to Schafer's curiosity about the disturbance of the ankle-jerk in myxœdema.

He had little interest in outside Committee work which he tended to regard as a waste of time outside his terms of reference as a Professor of Medicine, but internally at his Medical School he was active in safeguarding and promoting the development of research not only in his own department but in other fields as well.

Peter Sharpey-Schafer was not an easy man to know. Sometimes he was aloof and unsociable, but mainly because he was shy. He loved poking fun at his colleagues, sometimes under circum- 
stances in which his humour was not appreciated. In his serious moods he was wise and shrewd in judgement. He could seem casual in his approach to patients but beneath this facade he had a deep personal concern, often shown by anxiety and worry and endless effort to do his best in any difficult clinical situation. He was certainly an artist by nature-and to a small circle of friends he would shyly show his candid camera studies and his splendid colour prints of flowers and butterflies. He would spend long summer afternoons looking for wild orchids or chasing butterflies and explaining them to his children. He read much and widely, especially biography, military, naval, and political history, but he was also an enthusiastic and uncritical reader of lurid science fiction He was twice married, his second wife being his erstwhile collaborator, Sheila Howarth. He had two sons and three daughters.

Much of his work remained unpublished. He could produce from a drawer fascinating photographs or tracings to settle many scientific arguments. He loved his research for the pleasure of doing it and not for the exhibition that might follow. For nearly a century the Schafers have influenced British medical thought-a long span of exemplary effort.

Like his colleague, Wood, he died prematurely at 55 . His challenging provocative character will be missed for such men are unique.

JOHN MCMichaEL

\section{Professor E. P. Sharpey-Schafer published 71 scientific papers of which the following are outstanding examples:}

The effect of pituitary thyrotrophic extract in subjects with low basal metabolic rates. Quart. J. Med. (1939), 8, 195 (with I. Schrire).

Pterygo-nuchal infantilism. Lancet (1941), 2, 559.

Blood changes following controlled hæmorrhage in man. Lancet (1941), 2, 393 (with J. Wallace).

Retention of injected serum in the circulation. Lancet (1942), 1, 699 (with J. Wallace).

Circulatory overloading following rapid intravenous injections. Brit. med. J. (1942), 2, 304 (with J. Wallace).

Cardiac output in man by a direct Fick method. I. Effects of posture and venous pressure change. II. Effects of atropine, adrenaline and heart rate. Brit. Heart J. (1944), 6, 33 (with J. McMichael).

Post-hæmorrhagic fainting: study by cardiac output and forearm flow. Lancet (1944), 1, 489 (with H. Barcroft, O. G. Edholm, and J. McMichael).

Cardiac output in severe anæmia. Clin. Sci. (1944), 5, 125.

The action of intravenous digoxin in man. Quart. J. Med. (1944), N.S., 13, 123 (with J. McMichael).

Effects of venesection in low output heart failure. Clin. Sci. (1946), 6, 41 (with S. Howarth and J. McMichael).

Low blood pressure phases following hæmorrhage. Lancet (1947), 1, 18 (with S. Howarth). Cardiac output and peripheral blood flow in arteriovenous aneurysm. Clin. Sci. (1948), 7, 35 (with S. M. Cohen, $O$.
G.Edholm, S. Howarth, and J. McMichael).

Postural changes in the peripheral blood flow of normal subjects with observations on vasovagal fainting reactions as a result of tilting, the lordotic posture, pregnancy, and spinal anæsthesia. Clin. Sci. (1950), 9, 79 (with W. Brigden
and S. Howarth).

A method of estimating the collateral resistance during obstruction of the main artery to a limb. Lancet (1951), 1, 81 (with A. C. Dornhorst). The "Mess Trick" and the "Fainting Lark". Brit. med. J. (1951), 2, 382 (with P. Howard, G. L. Leathart, and A. C.
Dornhurst). Effects of coughing on intrathoracic pressure, arterial pressure and peripheral blood flow. J. Physiol. (Lond.) (1953),
122, 351.

The mechanism of syncope after coughing. Brit. med. J. (1953), 2, 860.

Effects of Valsalva's manouvre on the normal and failing circulation. Brit. med. J. (1955), 1, 693.

Syncope. Brit. med. J. (1956), 1, 506.

Circulatory reflexes in chronic disease of the afferent nervous system. J. Physiol. (Lond.) (1956), $134,1$.

Absent circulatory reflexes in diabetic neuritis. Lancet (1960), 1, 559 (with P. J. Taylor).

Venous tone (based on the Oliver-Sharpey Lectures, R.C.P., 1961). Brit. med. J. (1961), 2, 1589. 